\title{
SERVITE
}

\section{Pelatihan untuk Diversifikasi Produk Turunan Olahan Singkong di Desa Nanggerang - Bogor}

\author{
Laila Febrina $^{1}$, Julfi Restu Amelia ${ }^{2}$, Soecahyadi ${ }^{3}$, Ira Mulyawati ${ }^{4}$ \\ 1,2,3,4 Universitas Sahid Jakarta - Indonesia
}

\begin{abstract}
ABSTRAK
Singkong merupakan komoditi potensial untuk dikembangkan di Desa Nanggerang, Tajurhalang, Bogor. Saat ini, produk olahan singkong yang terdapat di desa tersebut hanya dalam bentuk keripik singkong, sehingga perlu diversifikasi dalam bentuk produk olahan lainnya yang dapat memberikan nilai tambah bagi komoditi singkong. Tujuan dan sasaran kegiatan ini adalah peningkatan partisipasi masyarakat Desa Nangerang melalui program pelatihan diversifikasi produk turunan olahan singkong. Prosedur pelaksanaan kegiatan PPDM Ecosavva di Desa Nanggerang yakni melaksanakan sosialisasi, pelatihan, serta pendampingan dalam diversifikasi produk turunan olahan singkong yakni tepung MOCAF (Modified Cassava Flour), mie mocaf free gluten, dan biskuit MOCAF. Hasil kegiatan adalah partisipasi masyarakat dalam mengikuti kegiatan sosialisasi dan pelatihan cukup aktif, yang dapat dilihat dari tingkat partisipasi mengikuti sesi pelatihan tidak berkurang sampai akhir kegiatan. Hasil kegiatan juga menunjukkan, pengetahuan mitra dan peserta tentang pengolahan produk turunan singkong berupa MOCAF, mie MOCAF dan biskuit MOCAF mengalami peningkatan.
\end{abstract}

Kata kunci: singkong; diversifikasi pangan; MOCAF; mie; biskuit

\section{Training for Processed Cassava Derivative Products Diversification in Nanggerang Village - Bogor}

\begin{abstract}
Cassava is a potential commodity to be developed in Nanggerang Village, Tajurhalang, Bogor. Currently, in Nanggerang Village, cassava is only processed into cassava chips, so it is necessary to conduct training on the diversification of cassava products which can provide added value to the commodity. The aim of this activity is to increase community participation in Nangerang through a training program for diversification of processed cassava derivative products. The procedure for implementing PPDM Ecosavva activities in Nanggerang Village is to carry out socialization, training, and assistance in the diversification of processed cassava derivative products, namely MOCAF flour (Modified Cassava Flour), gluten free mocaf noodles, and MOCAF biscuits. The results of the activity show that community participation in socialization and training is quite active, which can be seen from the tabile number of participants who attend each training session until the end of the activity. The results also showed that the knowledge of partners and participants about the processing of cassava derivative products in the form of MOCAF, MOCAF noodles and MOCAF biscuits has increased.
\end{abstract}

Keywords : cassava; food diversification; MOCAF; noodle; biscuit 


\section{PENDAHULUAN}

Desa Nanggerang di Kecamatan Tajurhalang, Kabupaten Bogor, Propinsi Jawa Barat, memiliki luas wilayah sekitar 245.000.000 hektar. Desa itu mempunyai komoditi potensial untuk dikembangkan yaitu singkong. Selama ini singkong hanya diolah menjadi keripik, sehingga perlu diversifikasi dalam bentuk produk olahan lain yang dapat memberikan nilai tambah bagi komoditi itu. Diversifikasi pangan merupakan upaya untuk mendorong masyarakat agar memvariasikan makanan pokok yang dikonsumsi sehingga tidak fokus pada satu jenis saja. Diversifikasi pangan juga bermanfaat untuk memperoleh nutrisi dari sumber gizi yang lebih beragam dan seimbang (Dharmawan, 2016).

Singkong merupakan komoditi produk pangan yang dapat diunggulkan menjadi pendukung gerakan peningkatan konsumsi dan ketahanan pangan nasional, karena komoditi tersebut tersedia di hampir semua daerah di Indonesia, memiliki harga yang murah, serta dapat menjadi alternatif sumber karbohidrat utama dalam susunan menu makanan sehari-hari.

Universitas Sahid bekerjasama dengan Pemerintah Desa Nangerang Kabupaten Bogor melaksanakan pelatihan diversifikasi produk turunan olahan singkong yang merupakan bagian dari Program Pengembangan Desa Mitra (PPDM), dengan melibatkan dua kelompok mitra: kelompok mitra pengrajin industri keripik singkong, dan kelompok karang taruna RW 05 Desa Nanggerang.

Dari identifikasi tim pengabdian yang dilakukan, terdapat beberapa permasalaan mitra. Permasalahan pada mitra pertama, kelompok industri singkong Desa Nanggerang, lebih diutamakan untuk menjawab kebutuhan diversifikasi pangan olahan pada komoditi singkong sehingga dapat memberikan nilai tambah ekonomis bagi mitra. Identifikasi permasalahan pada mitra kedua, kelompok Karang Taruna RW 05, lebih diutamakan pada mengoptimalkan kegiatan pemberdayaan masyarakat untuk ikut bersama dalam menyukseskan program pemerintah dalam program diversifikasi pangan mengingat peran masyarakat sangat penting dalam mendukung keberhasilan program tersebut.

Secara umum, tujuan dan sasaran kegiatan ini adalah peningkatan partisipasi masyarakat Desa Nangerang, Kabupaten Bogor melalui program pelatihan diversifikasi produk turunan olahan singkong.

\section{METODE PELAKSANAAN}

Pelaksanaan kegiatan Program Pengembangan Desa Mitra (PPDM) Ecosavva di Desa Nanggerang Kecamatan Tajurhalang dilakukan dengan melaksanakan sosialisasi, pelatihan, serta pendampingan untuk diversifikasi produk turunan olahan singkong yakni tepung MOCAF (Modified Cassava Flour), serta produk pangan olahan berbasis tepung mocaf 
fungsional: mie mocaf free gluten dan biskuit MOCAF. Tahapan kegiatan selanjutnya adalah melakukan evaluasi penilaian kegiatan yang telah dilakukan.

\section{HASIL DAN PEMBAHASAN}

Pada tahap persiapan, Tim PPDM berkoordinasi dengan Kepala Desa, Sekretaris Desa serta pemilik usaha keripik singkong. Dari pertemuan itu diperoleh kesepakatan pelaksanaan. Para pihak menyambut baik dan berharap, masyarakat desa mendapat manfaat dari kegiatan ini. Pelatihan diversifikasi produk turunan olahan singkong disampaikan oleh Dede Saputra M.Si yang merupakan tenaga ahli di Kementerian Perindustrian Republik Indonesia. Kegiatan pelatihan dilaksanakan di kantor Desa Nanggerang. Produk pertama yang diajarkan yaitu MOCAF (Modified Cassava Flour). Secara definitif, mocaf merupakan produk tepung dari singkong yang diproses menggunakan prinsip memodifikasi sel singkong secara fermentasi, dengan mikroba BAL (bakteri asam laktat) mendominasi selama proses fermentasi tepung singkong.

Mikroba yang tumbuh menghasilkan enzim pektinolitik dan sellulolitik yang dapat menghancurkan dinding sel singkong, sedemikian rupa sehingga terjadi liberasi granula pati. Mikroba tersebut juga menghasilkan enzim-enzim yang menghidrolisis pati menjadi gula dan selanjutnya mengubahnya menjadi asam- asam organik, terutama asam laktat. Hal tersebut akan menyebabkan perubahan karakteristik dari tepung yang dihasilkan berupa naiknya viskositas, kemampuan gelasi, daya rehidrasi, dan kemudahan melarut. Demikian pula, cita rasa mocaf menjadi netral dengan menutupi cita rasa singkong sampai 70\% (Subagio, 2008). Komponen yang terdapat pada MOCAF tidak sama persis dengan komponen yang terkandung pada tepung terigu, antara lain kandungan gluten yang tidak dimiliki tepung MOCAF tetapi dimiliki oleh tepung terigu. Gluten diketahui sebagai bahan yang sulit dicerna dengan baik oleh anak autis, celiac disease, dan penderita diabetes melittus.

Kebanyakan anak penyandang autis mempunyai masalah dalam proses mencerna atau memecah protein gluten. Penyandang celiac disease yang mengkonsumsi gluten akan mengalami reaksi imun yang berlebih dan merusak dinding usus halus penderita tersebut (Mulloy, 2009).

Tepung MOCAF mengandung karbohidrat yang tinggi dan gelasi yang lebih rendah dibandingkan tepung terigu. MOCAF memiliki karakteristik derajat viskositas (daya rekat), kemampuan gelasi, daya rehidrasi, dan kemudahan larut yang lebih baik dibandingkan tepung terigu (Subagio, 2008). Tepung MOCAF juga memiliki kandungan serat terlarut lebih tinggi daripada tepung tapioka memiliki kandungan kalsium lebih tinggi $58 \%$ dibanding padi $6 \%$ dan gandum 16\%, mempunyai daya kembang setara dengan gandum tipe II (kadar protein menengah), dan daya cerna lebih tinggi dibandingkan dengan tapioka gaplek. 
Menurut Moorthy (2004), ukuran granula MOCAF menunjukan variasi yang besar yaitu sekitar 5-40 $\mu \mathrm{m}$ dengan bentuk bulat dan oval. Kadar pati pada MOCAF lebih tinggi dibandingkan dengan tepung terigu, sedangkan kadar air yang terdapat pada MOCAF lebih rendah sehingga menyebabkan lebih tahan terhadap pertumbuhan mikroba yang dapat menyebabkan kerusakan produk (Putri \& Susatyo, 2015). Kegiatan pembuatan tepung MOCAF terdapat pada Gambar 1.

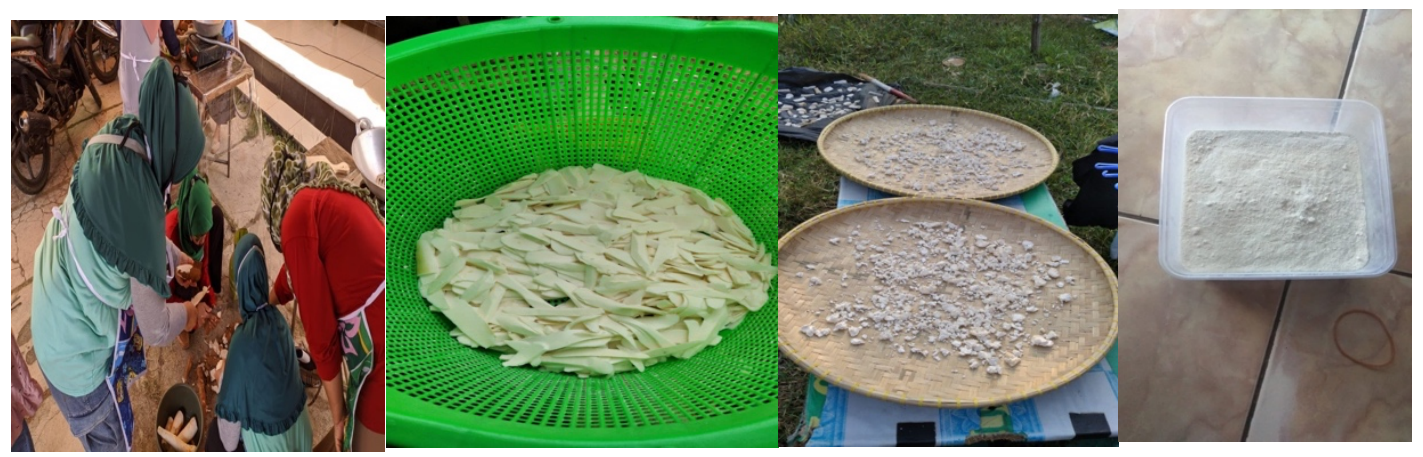

Gambar 1. Kegiatan dalam pembuatan tepung MOCAF

Tahapan pembuatan tepung MOCAF adalah sebagai berikut:

Sortasi. Sebelum singkong diproses, sortasi dilakukan untuk memisahkan singkong yang rusak dan tidak memenuhi standar mutu. Pada dasarnya semua varietas singkong dapat digunakan sebagai bahan baku MOCAF, namun singkong ideal yang sebaiknya digunakan adalah varietas singkong yang bisa dimakan, berumur sebaiknya sekitar 8-12 bulan, masih segar, tidak busuk, dan tidak bercak-bercak hitam, dan lama penyimpanan maksimal 2 hari.

Pengupasan. Pengupasan kulit singkong dilakukan dengan menggunakan pisau. Singkong yang telah dikupas sebaiknya ditampung dalam bak yang berisi air untuk menghindari warna kecoklatan sekaligus menghilangkan asam Sianida (HCN).

Pencucian. Singkong yang telah melalui proses pengupasan dicuci menggunakan air bersih, hindari penggunaan air yang mengandung kaporit atau terkontaminasi bahan kimia karena dapat menghambat pertumbuhan bakter fermentasi. Pencucian singkong harus dilakukan hingga benar-benar bersih, baik kotoran maupun lendir pada umbi harus dihilangkan.

Pemotongan. Singkong yang sudah bersih selanjutnya diiris tipis-tipis, dengan ketebalan chip 0,2-0,3 cm (opsional). Untuk jumlah yang besar, proses ini dapat dilakukan menggunakan mesin slicer. Namun ketajaman pisau harus senantiasa diperhatikan agar dapat menghasilkan chip yang bagus (tipis tetapi tidak hancur). Setelah berbentuk bulatan-bulatan tipis selanjutnya dimasukkan ke dalam wadah fermentasi.

Fermentasi. Proses fermentasi chips singkong dilakukan dengan menggunakan drum plastik atau bak plastik yang diisi air, kemudian dilarutkan bakteri starter MOCAF, ragi tempe, 
fermifan dan campuran dengan perbandingan 1:1000 $\mathrm{ml}$ dari volume chips dan air. Perendaman chips singkong diupayakan sedemikian hingga seluruh chips singkong tertutup air. Fermentasi dilakukan selama kurang lebih 2-3 hari (minimal 30 jam).

Pencucian. Setelah proses fermentasi selesai, dilakukan pencucian kembali untuk menghilangkan sifat asam pada chips singkong tidak berasa dan netral. Kemudian chips ditiriskan dengan menggunakan penjemur dari anyaman bambu, plat seng atau terpal.

Pengeringan. Pengeringan yang terbaik adalah pengeringan alami menggunakan sinar matahari. Untuk mempercepat proses pengeringan, sebaiknya chips ditiriskan terlebih dahulu atau dipres dengan mesin pres. Pengeringan alami dapat dilakukan dengan meletakkan chips di atas tampah atau sejenisnya. Diusahakan pengeringan dilakukan tidak lebih dari empat hari. Chips yang sudah kering dapat disimpan dalam karung bersih dan kering. Penyimpanan juga harus ditempat yang kering dan tidak lembab, (agar tidak lembab alasi karung dengan palet kayu).

Penepungan. Tahap akhir adalah tahap penepungan. Penepungan dilakukan jika chips sudah benar-benar kering hingga mencapai kadar air 13\%. Selanjutnya penepungan dilakukan dengan mesin penepung biasa seperti mesin-mesin penepung beras, dan sebagainya.

Pengayakan. Pengayakan dilakukan untuk mendapatkan tepung MOCAF yang lembut. Pengayakan dapat dilakukan secara manual dengan saringan atau dengan mesin dengan mesh 60-100. Tepung MOCAF yang halus menentukan mutu dari produk tersebut.

Produk selanjutnya yang diajarkan yaitu mie MOCAF free gluten. Konsumsi mie terus meningkat setiap tahun sejalan dengan pertambahan penduduk, dan dengan sendirinya mendorong peningkatan pemakaian dan impor terigu atau gandum.

Dari penelitian yang dilakukan di beberapa pilot plant, ternyata pati MOCAF dapat digunakan dalam pembuatan mie dengan mengganti terigu sampai $30 \%$. Salah satu jenis produk mie yang dapat dihasilkan dari pemanfaatan tepung MOCAF adalah mie kering. Mie kering berasal dari produk mi basah mentah yang dilakukan pengeringan sehingga mencapai kadar air sekitar $10 \%$.

Pengeringan dapat dilakukan dengan metode konvensional ataupun dengan pengeringan oven kering pada suhu $34-40^{\circ} \mathrm{C}$ dengan kadar kelembaban $70-75 \%$ selama lebih kurang lima jam. Adapun tahapan proses dalam pembuatan mie MOCAF adalah sebagai berikut:

Semua bahan dicampur dan diaduk dalam mixer sampai terbentuk adonan seperti dalam pembuatan roti. Adonan diuleni dengan tangan sampai semua bahan tercampur dengan sempurna. Sehingga terbentuk adonan yang kalis; 
Lembaran adonan diistirahatkan selama kurang lebih 15 menit supaya semua bahan tercampur secara sempurna, lalu di-roll dengan "Marcatto" (noodle cutter) sampai mencapai ketebalan kurang lebih 0,5 mm. Sampai pada tahap ini jenis mi yang dihasilkan adalah mi mentah (raw noodle).

Untuk memproduksi mi basah, mi mentah tersebut dibiarkan dulu kurang lebih 30 menit lalu direbus dalam air mendidih selama kurang lebih lima menit. Kemudian dicuci dengan air dingin sampai semua pati yang tidak tergelatinasi terbuang (ditandai dengan jernihnya air pencuci). Setelah ditiriskan, mie diolesi minyak goreng supaya lembaran-lembaran mie tidak lengket.

Selain mie produk yang selanjutnya diajarkan adalah biskuit MOCAF. Biskuit merupakan salah satu produk olahan pangan yang banyak disukai oleh masyarakat. Biskuit adalah sejenis makanan yang terbuat dari tepung terigu dengan penambahan bahan makanan lainnya, dengan proses pemanasan dan pencetakan (SNI 01-2973-1992).

Biskuit terbuat dari bahan dasar tepung terigu dan diproses dengan pemanggangan sampai kadar air kurang dari 5\% (Utomo, 2011). Tepung MOCAF dapat digunakan sebagai bahan baku, baik substitusi maupun seluruhnya. Hasil produk berbahan MOCAF tidak jauh berbeda dengan produk yang menggunakan bahan tepung terigu.

Penggunaan tepung MOCAF pada pembuatan biskuit dapat meningkatkan nilai ekonomis dari singkong dan tepung singkong, dapat mempertahankan kandungan protein pada produk biskuit yang dihasilkan serta dapat mengurangi penggunaan tepung terigu yang memiliki harga relatif lebih mahal (Arsyad, 2016).

Tahapan proses dalam pembuatan biskuit MOCAF adalah sebagai berikut: Kocok kuning telur dan gula halus hingga lembut, masukan vanilli, garam, aduk hingga rata. Masukkan margarin cair, aduk perlahan. Tambahkan tepung MOCAF, baking powder, cokelat bubuk, dan kacang, aduk hingga rata, dinginkan adonan. Ambil adonan, bentuk bola-bola kecil, tempatkan pada Loyang yang sudah dialasi kertas baking. Panggang adonan pada suhu 160-180 oC, selama 10 menit. Kegiatan pelatihan pembuatan mie dan biskuit MOCAF terdapat pada Gambar 2.
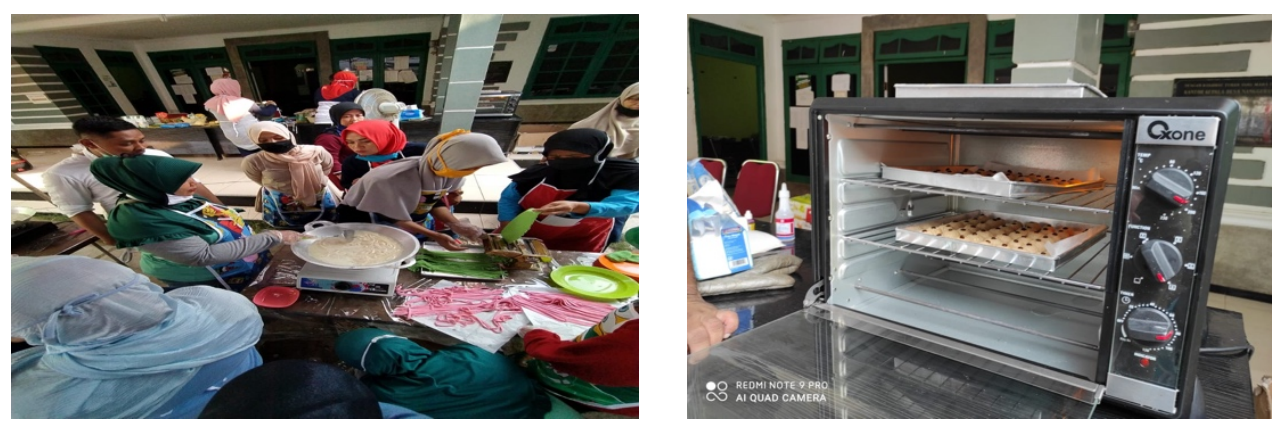

Gambar 2. Kegiatan pelatihan pembuatan mie dan biskuit MOCAF 
Setelah melakukan kegiatan proses pengolahan beberapa produk, kegiatan selanjutnya adalah melakukan kegiatan evaluasi. Evaluasi merupakan proses untuk menentukan relevansi, efektivitas dan dampak kegiatan dengan tujuan yang ditetapkan sebelumnya.

Evaluasi dilakukan pada beberapa aspek yakni terhadap instruktur kegiatan, pemahaman materi oleh peserta, serta penilaian terhadap penyelenggara kegiatan.

Hasil evaluasi kegiatan adalah sebagai berikut:

(1) Pelatihan diikuti oleh ibu-ibu PKK dan pelaku usaha yang terdapat di Desa Nangerang, sebanyak 24 peserta, 6 orang laki-laki dan 18 orang perempuan;

(2) Evaluasi terhadap instruktur kegiatan pada PKM menunjukan, sebanyak $92 \%$ responden menilai instruktur pada pelatihan menguasi dengan baik materi dan memotivasi peserta;

(3) Penilaian terhadap penyelenggaraan pelatihan mengenai ketersedian bahan serta efektivitas penyelenggaraan kegiatan menunjukan bahwa sebanyak $97 \%$ peserta memberikan penilaian baik dan sebanyak $3 \%$ memberikan penilaian amat baik. Dari masukan peserta terhadap kegiatan ini sangat mengharapkan kegiatan ini dapat diselenggarakan kembali dengan variasi olahan pangan yang lain, karena mereka merasakan manfaat yang dirasa pada kegiatan;

(4) dalam hal pemahaman dan pengetahuan peserta, sebanyak $98 \%$ peserta pada awalnya tidak mengetahui apa itu tepung MOCAF dan cara pembuatannya. Hanya $2 \%$ peserta telah mengetahui sebelumnya.

Dengan adanya pelatihan ini semua peserta merasakan manfaatnya dan memiliki tambahan pengetahuan cara membuat MOCAF dan tepung tapioka serta mengetahui cara mengolah tepung MOCAF menjadi pangan olahan jadi yang dapat dikembangkan menjadi sumber olahan rumah tangga atau untuk berwirausaha.

Pada pelatihan ini masyarakat sangat aktif mengikuti kegiatan dan antusias sejak awal kegiatan hingga akhir. Partisipasi masyarakat tidak berkurang.

\section{SIMPULAN}

Kesimpulan dari kegiatan ini adalah: (1) partisipasi masyarakat dalam mengikuti kegiatan sosialisasi dan pelatihan cukup aktif, yang dapat dilihat dari tingkat partisipasi yang mengikuti setiap sesi pelatihan relatif tidak berkurang sampai dengan akhir kegiatan; (2) pengetahuan mitra dan peserta tentang pengolahan produk turunan singkong berupa MOCAF, mie MOCAF dan biskuit MOCAF mengalami peningkatan setelah selesai mengikuti pelatihan. 


\section{DAFTAR PUSTAKA}

Arsyad, M. (2016). Pengaruh Penambahan Tepung Mocaf Terhadap Kualitas Produk Biskuit. Agropolitan, 3(3), 55-65.

Dharmawan, M.T. (2016). Pentingnya Diversifikasi Pangan untuk Mendukung Kedaulatan Pangan Indonesia. Fakultas Teknologi Pertanian. Universitas Gadjah Mada.

Kecamatan Tajurhalang. (2019). Desa Nanggerang. https://kecamatantajurhalang.bogorkab.go.id/desa/173. Diakses pada tanggal 01 September 2020.

Moorthy, S. N. (2004). Tropical sources of starch. In Starch in food (pp. 321-359). Woodhead Publishing.

Mulloy, A., Lang, R., O’Reilly, M., Sigafoos, J., Lancioni, G., \& Rispoli, M. (2010). Gluten-free and casein-free diets in the treatment of autism spectrum disorders: A systematic review. Research in Autism Spectrum Disorders, 4(3), 328-339.

Putri, A. E. V. T., Winarni, W., \& Susatyo, E. B. (2015). Uji proksimat dan organoleptik brownies dengan substitusi tepung mocaf (modified cassava flour). Indonesian Journal of Chemical Science, 4(3).

Subagio, A., Windrati, W. S., Witono, Y., \& Fahmi, F. (2008). Produksi Operasi Standar (POS): Produksi Mocal Berbasis Klaster. FTP Universitas Jember, Jember.

Utomo, J. S. (2001). Teknologi Pengolahan ubikayu dan ubijalar mendukung ketahanan Pangan. Makalah BALITKABI. Disampaikan pada Lokakarya Nasional Pengembangan Pangan Lokal dieselenggarakan oleh Badan Ketahanan Pangan, pada tanggal, 13-14. 